\title{
Term neonate with pneumopericardium, pneumothorax while on nasal continuous positive airway pressure (nCPAP)
}

\author{
Satyaranjan Pegu, Zarin Kalapesi
}

Department of Pediatrics, Regina Qu'Appelle Health Region, Regina, Saskatchewan, Canada

\section{Correspondence to} Dr Satyaranjan Pegu, satyapegu@gmail.com

Accepted 7 February 2017
CrossMark

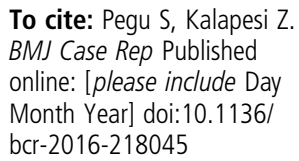

\section{DESCRIPTION}

This baby girl was born at 37 weeks to a woman aged 30 years. Her birth weight was $2.99 \mathrm{~kg}$. The antenatal period was uneventful with no risk factors for infection or any other high-risk conditions. The baby was born by normal vaginal delivery and required no active resuscitation at birth. Within a few minutes after birth, the baby developed respiratory distress, and hence was started on nasal continuous positive airway pressure, with pressure of 6 and $\mathrm{FiO}_{2}$ of 0.21 . Auscultation revealed diminished air entry on the left side of the chest as well as muffled heart sound. Chest X-ray showed a pneumopericardium and left pneumothorax (figures 1 and 2). As there was no X-ray prior to starting CPAP, it was not possible to determine whether the air leaks were present before or initiation of the CPAP contributed to that development. Fortunately, the baby did not develop any features of cardiac tamponade and remained haemodynamically stable. CPAP was discontinued after 1 hour and then oxygen via nasal cannula was provided for the next few hours to maintain normal saturations. Follow-up chest X-ray at 6 hours revealed near resolution of the pneumopericardium. Neonatal pneumopericardium is an uncommon condition with potential serious morbidity and mortality. It is known to be associated with other air leak syndromes (pneumomediastinum, pneumothorax, pneumoperitoneum, and subcutaneous and

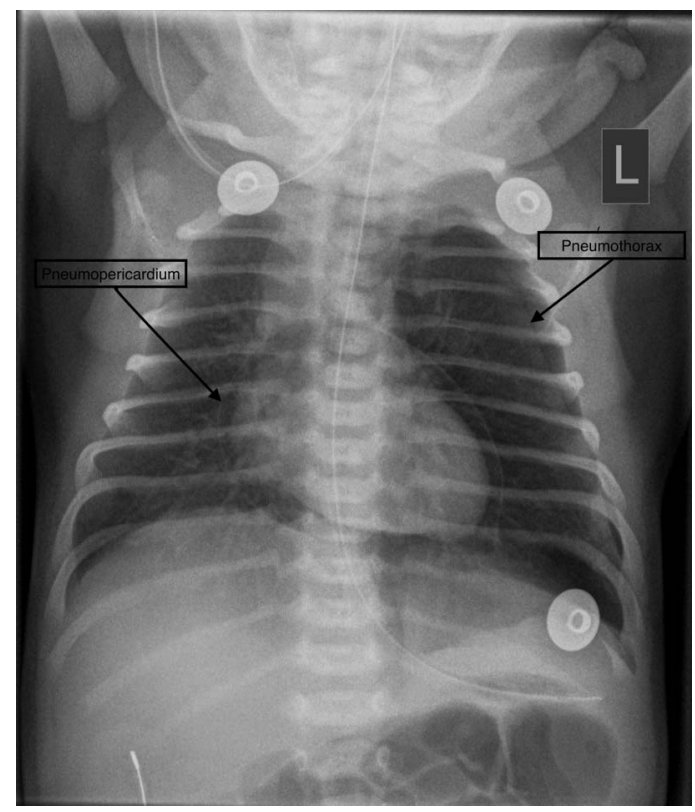

Figure 1 Chest $\mathrm{X}$-ray (A-P view) showing the pneumopericardium and left pneumothorax.

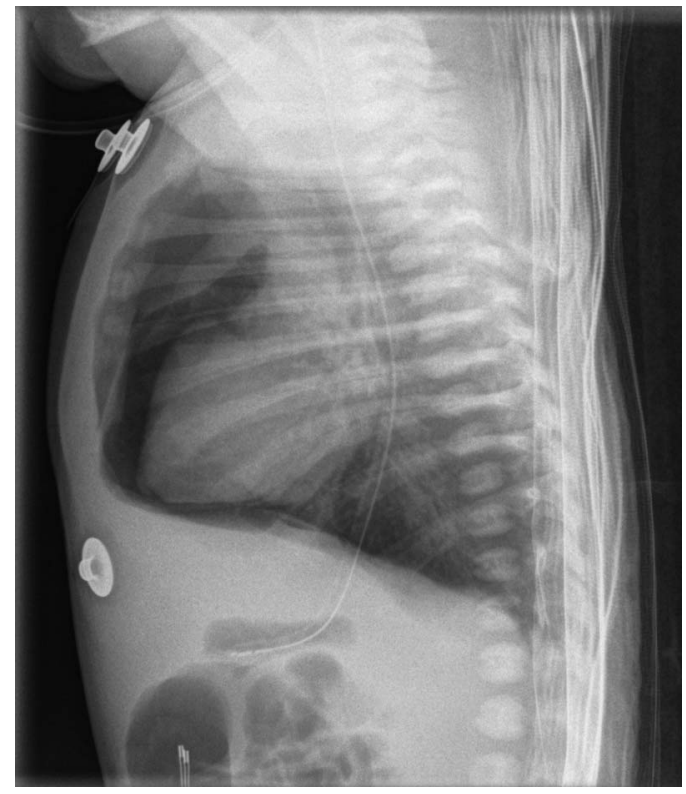

Figure 2 Chest X-ray (lateral view).

interstitial emphysema). Active resuscitation and assisted ventilation in premature babies with respiratory distress syndrome are potential risk factors for this condition. But there are also case reports where pneumopericardium has occurred spontaneously. ${ }^{1}$ Chest radiography can confirm the diagnosis of pneumopericardium and would show air surrounding immediately the heart shadow. Pneumopericardium could present with minimal clinical findings and no haemodynamic instability or manifest with tamponade-like symptoms with cardiac decompensation and death. Close monitoring would suffice for asymptomatic patients, but symptomatic patients with tension pneumopericardium would need emergency pericardiocentesis. ${ }^{23}$

\section{Learning points}

- Air leak like pneumothorax is fairly common in the new-born period, though pneumopericardium is rare. Chest X-ray can diagnose the condition.

- Asymptomatic pneumopericardium requires clinical monitoring for signs of development of cardiac tamponade.

- Pneumopericardium causing cardiac tamponade is an emergency condition with high morbidity and mortality and would require pericardiocentesis. 
Contributors SP was involved in care of the patient and drafted the manuscript. ZK was involved in the patient's care, revised and approved the final manuscript.

Competing interests None declared.

Patient consent Obtained.

Provenance and peer review Not commissioned; externally peer reviewed.

\section{REFERENCES}

1 Björklund L, Lindroth M, Malmgren N, et al. Spontaneous pneumopericardium in an otherwise healthy full-term newborn. Acta Paediatr Scand 1990;79:234-6.

2 Suryawanshi P, Klimek J. Preterm neonate with spontaneous pneumopericardium without any other associated air leaks. J Clin Diagn Res 2014;8:181-2.

3 Heckmann $\mathrm{M}$, Lindner $\mathrm{W}$, Pohlandt $\mathrm{F}$. Tension pneumopericardium in a preterm infant without mechanical ventilation: a rare cause of cardiac arrest. Acta Paediatr 1998;87:346-8.

Copyright 2017 BMJ Publishing Group. All rights reserved. For permission to reuse any of this content visit http://group.bmj.com/group/rights-licensing/permissions.

BMJ Case Report Fellows may re-use this article for personal use and teaching without any further permission.

Become a Fellow of BMJ Case Reports today and you can:

- Submit as many cases as you like

- Enjoy fast sympathetic peer review and rapid publication of accepted articles

- Access all the published articles

- Re-use any of the published material for personal use and teaching without further permission

For information on Institutional Fellowships contact consortiasales@bmjgroup.com

Visit casereports.bmj.com for more articles like this and to become a Fellow 